Magdalena Szczepańska

\title{
Ocena poselskiego projektu nowelizacji ustawy o emeryturach i rentach z Funduszu Ubezpieczeń Społecznych ${ }^{1}$
}

\author{
Assessment of the Deputies' Bill on Amending the Act on Pensions \\ from the Social Insurance Fund
}

\begin{abstract}
The proposed amendment contains regulations specifying the burden of proof in proceedings conducted by the pension body in relation to persons who acquired a benefit under the Act on Retirement Provision of Miners and Their Families. In the author's opinion, the acceptance of the proposed solution only in relation to the group of insured persons indicated in the bill raises doubts in the light of the constitutional principle of equality due to the fact that a similar situation regarding the calculation of pensions applies to other insured persons who acquired benefits under the Act on Retirement Provision of Employees and Their Families.
\end{abstract}

Keywords: pensions, miners, bill, social insurance

Projektowana nowelizacja zawiera regulacje określające ciężar dowodu w postępowaniach prowadzonych przez organ rentowy w stosunku do osób, które nabyły świadczenie na podstawie ustawy o zaopatrzeniu emerytalnymi górników i ich rodzin. W ocenie autorki przyjęcie zaproponowanego rozwiązania jedynie w stosunku do wskazanej w projekcie grupy ubezpieczonych budzi wątpliwości w świetle konstytucyjnej zasady równości ze względu na fakt, że w analogicznej sytuacji w zakresie przeliczania emerytury znajdują się inni ubezpieczeni, którzy nabyli świadczenia na podstawie ustawy o zaopatrzeniu emerytalnym pracowników i ich rodzin.

Słowa kluczowe: emerytury i renty, górnicy, projekt ustawy, ubezpieczenie społeczne

Doktor hab. nauk prawnych, adiunkt -

Uniwersytet Warszawski, Wydział Prawa i Administracji, kierownik Katedry Prawa

Ubezpieczeń, WARSZAWA, POLSKA •

magdalena.szczepanska@sejm.gov.pl • https://orcid.org/0000-0003-1040-5792

\section{Przedmiot projektu}

Projekt zakłada wprowadzenie regulacji prawnej, której podstawowym celem jest modyfikacja przepisów określających ciężar dowodu w postępowaniach prowadzonych przez organ rentowy w stosunku do osób, które nabyły świadczenie na podstawie ustawy z 1 lutego 1983 r. o zaopatrzeniu emerytalnymi górników i ich rodzin (Dz.U. 1995, poz. 154, ze zm.; dalej: ustawa o zaopatrzeniu emerytalnym

1 Ocena prawna poselskiego projektu ustawy o zmianie ustawy o emeryturach i rentach z Funduszu Ubezpieczeń Społecznych (druk sejmowy nr 3756) sporządzona 20 sierpnia 2019 r. na zlecenie zastępcy Szefa Kancelarii Sejmu; BAS-WAP 1670/19. 
górników). W projekcie ustawy przewidziano nową regulację określającą, że w stosunku do osób składających wniosek o ponowne obliczenie wysokości renty i emerytury, którym przysługiwało świadczenie emerytalne na podstawie ustawy o zaopatrzeniu emerytalnym górników i których świadczenia zostały ustalone przed dniem 31 grudnia 1998 r., organ rentowy przeprowadza postępowanie na podstawie dowodów znanych organowi z urzędu. Zawarto również propozycję regulacji, że w tym przypadku nie stosuje się przepisu art. 116 ust. 5. W projekcie określono również konsekwencje braku możliwości jednoznacznego ustalenia wysokości emerytury. Zaproponowano regulację, przewidującą, że jeżeli po przeprowadzeniu postępowania, o którym mowa w ust. 1, ujawnione dowody nie pozwalają na jednoznaczne ustalenie wskaźnika wysokości podstawy emerytury, przyjmuje się średnią wartość wynagrodzeń osoby składającej wniosek z roku wskazanego przez wnioskodawcę, uwzględniając przy tym składniki wynagrodzenia, od których nie były naliczane składki na ubezpieczenia rentowe i emerytalne.

Projektodawcy wskazali, że uzasadnieniem dla wprowadzenia projektowanych zmian jest zróżnicowanie pozycji ubezpieczonych, którzy nabyli prawo do świadczeń emerytalnych i rentowych na podstawie ustawy o zaopatrzeniu emerytalnym górników. Przepisy te zostały uchylone z dniem 31 grudnia 1998 r. przez art. 195 ust. 6 ustawy o emeryturach i rentach z Funduszu Ubezpieczeń Społecznych (t.j. Dz.U. 2018, poz. 1270, ze zm.; dalej: ustawa o emeryturach i rentach z FUS). W uzasadnieniu odniesiono się do możliwości złożenia wniosku o ponowne obliczenie wysokości emerytury górniczej na podstawie art. 110a ustawy o emeryturach i rentach z FUS i wskazano, że praktyka ta jest iluzoryczna $\mathrm{z}$ uwagi na fakt, że to od świadczeniobiorców wymaga się dostarczenia dokumentacji płacowej, na której podstawie organ emerytalny ma dokonać ponownego przeliczenia świadczenia. Ubezpieczeni w większości nie dysponują taką dokumentacją, gdyż zakłady pracy rzadko wydawały takie dokumenty, a dokumentacja płacowa zgromadzona $\mathrm{w}$ publicznym zasobie archiwalnym jest $\mathrm{z}$ wielu przyczyn niekompletna. $W$ wwiazku z powyższym zasadna i konieczna jest odpowiednia interwencja ustawodawcy w tym zakresie, właśnie $w$ postaci modyfikacji przepisów ustawy $z$ dnia 17 grudnia 1998 r. o rentach i emeryturach $z$ Funduszu Ubezpieczeń Społecznych. W opinii projektodawców przedstawione zmiany powinny ułatwić ponowne obliczanie emerytur górniczych świadczeniobiorcom i uzyskanie świadczeń we właściwej wysokości.

W uzasadnieniu wskazano, że kwestia regulowana $\mathrm{w}$ niniejszym projekcie może dotyczyć grupy do 10000 osób, a jej skutki finansowe dla budżetu Funduszu Ubezpieczeń Społecznych należy szacować na 240 mln złotych w skali roku.

\section{Adresaci projektu}

Punktem odniesienia dla obszaru normowania projektowanej ustawy o zmianie ustawy o emeryturach i rentach z FUS są przede wszystkim emeryci, którym 
przysługiwało świadczenie emerytalne na podstawie ustawy o zaopatrzeniu emerytalnym górników i których świadczenia zostały ustalone przed dniem 31 grudnia 1998 r. Projektowana ustawa dotyczyć będzie również ZUS, na który ma zostać nałożony obowiązek przeprowadzania postępowania na podstawie dowodów znanych organowi z urzędu (w obecnym stanie prawnym przedmiotową dokumentację jest zobowiązany dostarczyć organowi rentowemu ubezpieczony).

\section{Ocena skutków prawnych przyjęcia projektu}

1. Projektowana regulacja wpłynie na poprawę sytuacji prawnej ubezpieczonych, którzy nabyli prawo do świadczeń emerytalnych i rentowych na podstawie ustawy o zaopatrzeniu emerytalnym górników, ponieważ przeniesie ciężar dowodu w zakresie ustalenia wysokości świadczeń emerytalnych z ubezpieczonych na organ rentowy. W obecnym stanie prawnym obowiązek dostarczenia przez ubezpieczonego dowodów uzasadniających prawo do świadczeń z ubezpieczeń społecznych oraz ich wysokość został nałożony przez ustawodawcę w art. 116 ust. 5 ustawy o emeryturach i rentach z FUS oraz art. 80 ustawy z 13 października 1998 r. o systemie ubezpieczeń społecznych (t.j. Dz.U. 2019, poz. 300, ze zm.), jak również w art. 232 ustawy z 17 listopada 1964 r. - Kodeks postępowania cywilnego (t.j. Dz.U. 2018, poz. 1360). Nałożenie takiego obowiązku na ZUS wiąże się ze znacznym nakładem pracy, który musiałby w takiej sytuacji wykonać organ rentowy.

W ciągu ostatnich kilkudziesięciu lat wystąpił problem dotyczący wszystkich ubezpieczonych, polegający na tym, że regulacje określające sposób wyliczania emerytury, w szczególności okres zatrudnienia ubezpieczonego uwzględniany w formule wymiaru emerytury, nie były w pełni kompatybilne z przepisami dotyczącymi obowiązku przechowywania dokumentacji przez pracodawcę. Do roku 1991 okresy przechowywania dokumentacji płacowej odpowiadały długości okresu, który stanowił podstawę ustalania wymiaru emerytury i renty. Rozporządzenie Ministra Finansów z 15 stycznia 1991 r. w sprawie zasad prowadzenia rachunkowości (Dz.U. nr 10, poz. 35) w związku z wydłużeniem tego okresu analogicznie dostosowywało okres przechowywania tej dokumentacji. Następnie wprowadzono szczegółowe regulacje: rozporządzenie Ministra Pracy i Polityki Socjalnej z 28 maja 1996 r. w sprawie zakresu prowadzenia przez pracodawców dokumentacji w sprawach związanych ze stosunkiem pracy oraz sposobu prowadzenia akt osobowych pracownika (Dz.U. nr 62, poz. 286) oraz art. 125a pkt 4 ustawy o emeryturach i rentach z FUS. Obecnie istnieje obowiązek przechowywania dokumentacji płacowej przez 50 lat. W związku z powyższym należy zwrócić uwagę, że problem braku możliwości przeliczenia emerytury, ze względu na obowiązujące przepisy prawa, które mogło spowodować zniszczenie dokumentacji płacowej, może dotyczyć wszystkich ubezpieczonych, którzy nabyli świadczenia na podsta- 
wie ustawy z 14 grudnia 1982 r. o zaopatrzeniu emerytalnym pracowników i ich rodzin (Dz.U. nr 40, poz. 267, ze zm.), a nie tylko ubezpieczonych, którzy nabyli prawo do świadczeń emerytalnych i rentowych na podstawie ustawy z 1 lutego 1983 r. o zaopatrzeniu emerytalnym górników i ich rodzin. W konsekwencji przyjęcie zaproponowanego rozwiązania jedynie w stosunku do wskazanej w projekcie grupy ubezpieczonych budzi wątpliwości w świetle zasady równości wskazanej w art. 32 Konstytucji RP. Nie ma racjonalnych przesłanek uzasadniających wprowadzenie tego rodzaju rozwiązania prawnego jedynie dla wybranej grupy ubezpieczonych w sytuacji, gdy w analogicznej sytuacji prawnej znajduje się szerszy krąg emerytów uzyskujących świadczenia na podstawie reguł powszechnych wynikających $z$ art. 110a ustawy o emeryturach i rentach z FUS. Przepis ten przewiduje, że wysokość emerytury oblicza się ponownie od podstawy wymiaru ustalonej w sposób określony $\mathrm{w}$ art. 15, z uwzględnieniem art. 110 ust. 3, jeżeli do jej obliczenia wskazano podstawę wymiaru składki na ubezpieczenie społeczne lub ubezpieczenia emerytalne i rentowe na podstawie przepisów prawa polskiego przypadającą w całości lub w części po przyznaniu świadczenia, a wskaźnik wysokości podstawy wymiaru przed zastosowaniem ograniczenia, o którym mowa w art. 15 ust. 5, jest wyższy niż $250 \%$. Dotyczy on wszystkich osób objętych zakresem podmiotowym ustawy o emeryturach i rentach z FUS. Mechanizm ten ma zastosowanie $\mathrm{w}$ sytuacji spełnienia warunku kontynuowania podlegającego ubezpieczeniu zatrudnienia po nabyciu prawa do emerytury ${ }^{2}$.

W obecnym stanie prawnym generalna instytucja przeliczenia wysokości świadczenia określona $\mathrm{w}$ art. 109-111 ustawy o emeryturach i rentach z FUS umożliwia zwiększenie emerytury lub renty $\mathrm{w}$ wyniku uwzględnienia $\mathrm{w}$ podstawie wymiaru świadczenia okresów ubezpieczenia przypadających zarówno przed, jak i po przyznaniu emerytury/renty. Artykuł 110a dotyczy jednego ze wskazanych przez ustawodawcę przypadków ponownego obliczania wysokości emerytury. Podstawową zasadą obowiązującą przy zastosowaniu tej instytucji jest reguła, że do przeliczenia świadczenia nie można wykorzystać danych o uzyskiwanych dochodach, które nie wpływają w sposób pewny, lecz tylko przybliżony lub prawdopodobny, na ustalenie podstawy obliczenia wysokości emerytur i rent, jak np. przyjęcie hipotetycznej i uśrednionej wielkości premii ubezpieczonego $\mathrm{w}$ wyniku jej porównania $\mathrm{z}$ premiami wypłaconymi innym pracowni$\mathrm{kom}^{3}$. Od dnia 1 stycznia 2009 r. - na mocy art. 2 ustawy z 4 września 2008 r.

2 Zob. wyrok SA w Łodzi z 29 marca 2018 r., sygn. akt III AUa 319/17, LEX nr 2490978, a także Emerytury i renty $z$ FUS. Emerytury pomostowe. Okresowe emerytury kapitałowe. Komentarz do trzech ustaw emerytalnych, red. K. Antonów, LEX, komentarz do art. 109, art. 110, art. 110(a), art. 111 ustawy o emeryturach i rentach z Funduszu Ubezpieczeń Społecznych.

3 Zob. wyrok SN z 4 lipca 2007 r., sygn. akt I UK 36/07, LEX nr 390123, oraz wyroki SA: w Warszawie z 20 czerwca 2007 r., sygn. akt III AUa 482/07, OSA 2009, nr 1, poz. 1; we Wrocławiu z 29 sierpnia 2012 r., sygn. akt III AUa 233/12, LEX nr 1216267. 
o zmianie ustawy o emeryturach i rentach z Funduszu Ubezpieczeń Społecznych (Dz.U. nr 192, poz. 1180) możliwe stało się przeliczanie świadczeń z uwzględnieniem minimalnego wynagrodzenia za okresy, w których ubezpieczony pozostawał w stosunku pracy, lecz nie mógł ustalić podstawy wymiaru składek ze względu na brak dokumentacji płacowej ${ }^{4}$.

2. W projekcie ustawy wprowadzono odstępstwo od zasady nieuwzględniania przy ustalaniu wysokości wyliczonej ponownie emerytury dochodów nieudokumentowanych i zaproponowano konstrukcję przyjęcia dochodów estymowanych na podstawie danych istniejących w przypadku braku środków dowodowych. Przyjęcie takiej regulacji budzi wątpliwości w świetle obecnie stosowanych reguł. Zaproponowano regulację przewidującą, że jeżeli po przeprowadzeniu postępowania, o którym mowa w ust. 1, ujawnione dowody nie pozwalają na jednoznaczne ustalenie wskaźnika wysokości podstawy emerytury, przyjmuje się średnią wartość wynagrodzeń osoby składającej wniosek z roku wskazanego przez wnioskodawcę, uwzględniając przy tym składniki wynagrodzenia, od których nie były naliczane składki na ubezpieczenia rentowe i emerytalne. Tego rodzaju norma byłaby bardzo korzystna dla tej grupy emerytów w dwóch aspektach. Po pierwsze, mogliby oni mieć przeliczone świadczenie na podstawie wybranego przez siebie relatywnie krótkiego okresu - 1 roku (obecnie zasadą jest okres 10 lat z ostatnich dwudziestu lub $20 \mathrm{z}$ całego okresu kariery zawodowej) najprawdopodobniej o najwyższych dochodach. Po drugie, pozostała grupa emerytów, uzyskująca świadczenia emerytalne na zasadach powszechnych, może mieć ewentualnie uwzględnione dochody na poziomie wynagrodzenia minimalnego. Natomiast w przypadku przyjęcia projektowanego rozwiązania nie będzie miał do nich zastosowania korzystniejszy mechanizm wyboru jednego roku z najwyższymi przychodami, ponieważ został on przewidziany tylko dla osób, które nabyły świadczenie na podstawie ustawy z 1 lutego 1983 r. o zaopatrzeniu emerytalnymi górników i ich rodzin.

Przyjęcie zaproponowanego rozwiązania jedynie w stosunku do wskazanej w projekcie grupy ubezpieczonych budzi wątpliwości w świetle zasady równości wskazanej w art. 32 Konstytucji.

\section{Podsumowanie}

Analizowany projekt przewiduje wprowadzenie nowej regulacji prawnej, której podstawowym celem jest modyfikacja przepisów określających ciężar dowodu $\mathrm{w}$ postępowaniach prowadzonych przez organ rentowy w stosunku do osób, które nabyły świadczenie na podstawie ustawy z 1 lutego 1983 r. o zaopatrzeniu emerytalnym górników i ich rodzin. Projektowana ustawa zawiera uregulowanie

4 Emerytury i renty z FUS. Emerytury pomostowe, op. cit. 
$\mathrm{w}$ tej kwestii oraz normę przewidującą procedurę stosowaną w przypadku braku dokumentacji. Wejście w życie przedmiotowej ustawy poprawiłoby sytuację prawną wymienionej grupy ubezpieczonych w zakresie ponownego ustalania wysokości emerytury. Projektodawcy ustawy wskazali jako źródło finansowania kosztów realizacji przedmiotowej ustawy Fundusz Ubezpieczeń Społecznych, a ze względu na jego deficyt w konsekwencji byłby to budżet państwa. Ponieważ w analogicznej sytuacji w zakresie przeliczania emerytury znajdują się również ubezpieczeni, którzy nabyli świadczenia na podstawie ustawy z 14 grudnia 1982 r. o zaopatrzeniu emerytalnym pracowników i ich rodzin, przyjęcie zaproponowanego rozwiązania jedynie w stosunku do wskazanej w projekcie grupy ubezpieczonych budzi wątpliwości w świetle zasady równości wskazanej w art. 32 Konstytucji.

\section{Bibliografia}

Emerytury i renty z FUS. Emerytury pomostowe. Okresowe emerytury kapitałowe. Komentarz do trzech ustaw emerytalnych, red. K. Antonów, LEX. 